\title{
O trabalho duplicado: a divisão sexual no trabalho e na re- produção - um estudo das trabalhadoras do telemarketing
}

\author{
NOGUEIRA, Claudia Mazzei. São Paulo: Expressão Popular, 2006. 240p.
}

As pesquisas sobre teleatendimento no Brasil têm, gradativamente, despertado o interesse de pesquisadores que passaram a observar o crescimento de um novo setor da economia em expansão em todo o mundo: o teleatendimento.

É inegável sua capacidade de geração de empregos formais em uma sociedade marcada pelo desemprego. Contudo, fazse necessário analisar a organização do trabalho e as formas de gestão da força de trabalho que, a despeito do emprego de alta tecnologia, apóiam-se em práticas vivenciadas no período de expansão da indústria.

O livro de Claudia Mazzei Nogueira vem contribuir para a ampliação dos conhecimentos nesse campo, enfocando a existência, ou não, de alterações na divisão sexual do trabalho no âmbito do trabalho produtivo e reprodutivo em uma categoria profissional predominantemente feminina.

Esse setor adquire fundamental importância para a compreensão da atual dinâmica do trabalho na sociedade capitalista, pois acirra a competitividade entre as empresas, posto que a agilidade das comunicações acelera as negociações e, nas palavras de Nogueira, estabelece a "mercantilização da informação”.

Se do lado do empresariado o telemarketing se configura como um aspecto positivo na concretização dos negócios, do lado das trabalhadoras o mesmo não se verifica. São predominantemente mulheres, jovens, com parcela significativa de pessoas que obtiveram seu primeiro emprego nesse setor - mas que vivenciam condições de trabalho nocivas às saúdes física e mental.

A organização do trabalho observada nas empresas do setor apóia-se na eliminação dos tempos mortos, associando alta tecnologia a velhos preceitos de controle dos trabalhadores, aperfeiçoados pela tecnologia, permitindo maior extração da mais-valia.
A forte e constante pressão por atendimentos em tempos cada vez mais constritos, o difícil relacionamento com clientes e, sobretudo, com as chefias intermediárias, que ficam à escuta sugerindo atitudes e comportamentos, têm levado essas trabalhadoras a altos níveis de esgotamento, mascarados pela medicina do trabalho empresarial, que passa a lidar com o problema de forma individualizada, sem considerar seu caráter coletivo.

Tanto a estratégia empresarial como as condições de trabalho no setor conduzem a índices expressivos de rotatividade nessa categoria, o que é analisado, apropriadamente, em duas dimensões: por um lado, a "descartabilidade" da força de trabalho e, por outro, a conformação de reais entraves para a organização desta categoria profissional, dificultando a construção do pertencimento de classe (p. 56).

O cotidiano das teleoperadoras é retratado de forma a ressaltar a repetitividade no trabalho produtivo: são 6 horas diárias, sentadas à frente de um microcomputador, sendo ouvidas por representantes da empresa, informando usuários em tempo médio de atendimento em torno de 29 segundos. Além desse tempo médio, há a observância determinada pela Anatel, que reza que os usuários não devem permanecer em fila de espera por tempo superior a 10 segundos. Nessa perspectiva, a opção empresarial é pela compressão do tempo no trabalho e não pela ampliação dos postos de trabalho, que, em princípio, poderia amenizar esse tipo de pressão.

Cláudia Nogueira mostra que os diálogos são padronizados por meio do estabelecimento de scripts para o alcance desses objetivos, ressaltando a função da linguagem no trabalho como portadora de significados e, portanto, a estandardização, que visa transmitir valores empresariais aos usuários com determinada uniformidade.

A empresa analisada apresenta uma jornada de trabalho de 6 horas, com $15 \mathrm{mi}-$ 
nutos de intervalo e 5 minutos destinados a pausas particulares. Situação ironicamente "mais favorável" em relação às empresas terceirizadas, que adotam apenas os 15 minutos de intervalo, destinados a lanche, solução de problemas pessoais etc.

As condições de trabalho e a postura das chefias em relação a pausas restritas apontadas pela autora abrem campo fértil de investigação para a área da saúde, em especial à Nefrologia, à Psiquiatria e à Psicologia.

Decorrem dessas condições de trabalho altos índices de absenteísmo na categoria, assim como alta rotatividade. $\mathrm{O}$ mal-estar, tal como analisado por autores a exemplo de Christophe Dejours, é a síntese das alterações físicas e subjetivas advindas do processo de trabalho. Sua manifestação inicia-se no absenteísmo, resultando em abandono da profissão, e apresenta sintomas relacionados à depressão, ao estresse, à exaustão e à ansiedade.

A preocupação patronal com a saúde das trabalhadoras limita-se a disponibilizar um ambulatório, médicos e outros especialistas para atenderem diversas demandas nesse campo. Os casos de LER/DORT são muitas vezes negligenciados pela equipe médica, que indica tratamentos paliativos, evitando conceder licenças médicas. As trabalhadoras, por sua vez, preferem omitir seus problemas de saúde temendo retaliações que as conduzam ao desemprego.

Os indícios de que a saúde física destas trabalhadoras tem sido afetada pelo trabalho são muitos: na empresa pesquisada, $7,5 \%$ dos trabalhadores encontravam-se em licença médica e apenas 1,5\% era do sexo masculino.

Se do lado do trabalho produtivo a mulher trabalhadora no setor de telemarketing vivencia situações precarizadas de trabalho, no que tange ao trabalho reprodutivo não é diferente. Nesse último aspecto, as mulheres apresentam uma introjeção acerca da responsabilização das tarefas domésticas e, portanto, o sexo masculino "ajuda”, mas não tem responsabilidade por sua realização. Ajudar não é, naturalmente, compartilhar, dividir. A mensagem subjacente é: “ajudo quando posso", diferente da compreensão de que os afazeres domésticos, o cuidado com filhos, idosos, pessoas com alguma espécie de dependência são atribuições de ambos os sexos.

Apreende-se que a jornada de trabalho de 6 horas indica, pelo lado dos empresá- rios, ser suficiente para atingir determinada produtividade, a qual comprovadamente decresce significativamente após esse período. Do lado do trabalho reprodutivo, possibilita realizar as tarefas domésticas e, como bem aponta a autora, "na sociedade patriarcal, as prioridades femininas residem fundamentalmente na esfera doméstica” (p. 111).

Os arranjos familiares, por vezes, envolvendo também outras mulheres, é a solução encontrada pelas mulheres trabalhadoras para os cuidados de seus filhos. Nesse sentido, às suas mães é destinada a tarefa de cuidar dos filhos nas horas de trabalho das filhas.

A remuneração surge como um fator imprescindível no sustento familiar e não complementar, reafirmando pesquisas anteriores desenvolvidas pela autora que apontam que a inserção no mercado de trabalho está menos relacionada à emancipação da mulher, mas, de fato, ela se dá por questões de sobrevivência e estão estreitamente vinculadas ao desemprego masculino crescente.

Tal situação reafirma posições hierárquicas diferenciadas na sociedade como um todo, reservando à mulher salários inferiores em relação aos homens, assim como as responsabilidades domésticas. Nesse aspecto, Claudia Nogueira irá apontar o papel feminino para a manutenção e reprodução da lógica capitalista na sociedade (p. 125).

As diferenças entre os sexos compreendidas como construções sociais e não como "destinos biológicos" indicam que a sociedade instaura patamares de poder e dominação. Assim, estabelece segregações e valorações que acabam por determinar um valor para o trabalho masculino diferente do das mulheres, não só no que concerne à remuneração, mas também quanto ao reconhecimento social da tarefa e da profissão, além da "naturalização" da responsabilidade pelo trabalho reprodutivo.

Desta forma, a análise tecida por Claudia Nogueira vem somar-se a outras pesquisas, tais como as realizadas por Daniele Kergoat, Liliana Segnini, Helena Hirata entre outras, confirmando que, tanto no espaço produtivo, como no reprodutivo, a divisão sexual do trabalho está presente, reafirmando relações de opressão e reproduzindo os valores da sociedade patriarcal. 
A análise teórica é feita com competência e profundidade, focalizando o trabalho como categoria fundante do ser social, apoiando-se em Marx, Engels, Luckács, Antunes e Mészaros. Tal exame, articulado à pesquisa empírica, permite reafirmar a divisão sexual do trabalho como um fenômeno do processo histórico e distante de uma suposta neutralidade.

A urgência em vivenciarmos uma sociedade capaz de "metamorfosear" a divisão sexual do trabalho adquire ao menos um sinal de probabilidade apontado nessa pesquisa: a consciência, por parte das mulheres que sofrem a opressão da sociedade patriarcal, da importância de uma divisão sexual do trabalho mais justa e igualitária as leva a educarem seus filhos e filhas a partir de princípios que conduzam a relações menos desiguais entre homens e mulheres.

Selma Venco

Pesquisadora colaboradora do Instituto de Filosofia e Ciências Humanas da Universidade Estadual de Campinas. Professora convidada da Faculdade de Educação da Universidade Estadual de Campinas. E-mail: selmavenco@uol.com.br 